\title{
DETERMINATION OF TITANIUM IN ZINC ASH BY FAAS AFTER DIGESTED USING ULTRASOUND-ASSISTED EXTRACTION
}

\author{
Buse DAĞCI İSMAİLLER ${ }^{1}$ D, Fatma KURŞUN BAYSAK $^{1}$ D, Cemile OZCAN $^{1 * \mathbb{D}}$ \\ ${ }^{I}$ Department of Chemistry, Science and Art Faculty, Kirklareli University, Kirklareli, Turkey
}

\begin{abstract}
In this study, it is aimed to determine the amount of Ti (titanium) in waste ash samples taken from galvanizing factories by using flame atomic absorption (FAAS). Various time periods and different solvent mixtures were examined by using ultrasound-assisted extraction for digestion of zinch ash which taken from various processes of galvanizing metal sheet or pipe. The best solvent mixtures

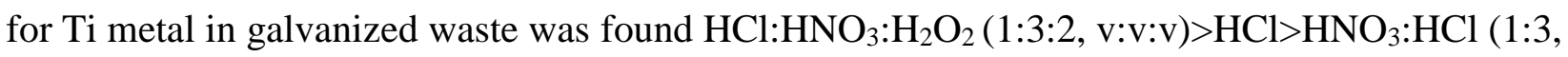
$\mathrm{v}: \mathrm{v})>\mathrm{HNO}_{3}>\mathrm{HNO}_{3}: \mathrm{H}_{2} \mathrm{SO}_{4} \quad(3: 1, \quad \mathrm{v}: \mathrm{v})>\mathrm{HNO}_{3}: \mathrm{H}_{2} \mathrm{SO}_{4} \quad(1: 1, \quad \mathrm{v}: \mathrm{v})>\mathrm{HNO}_{3}: \mathrm{H}_{2} \mathrm{SO}_{4} \quad(3: 2$, $\mathrm{v}: \mathrm{v})>\mathrm{HNO}_{3}: \mathrm{H}_{2} \mathrm{SO}_{4}(2: 1, \mathrm{v}: \mathrm{v})$, respectively.
\end{abstract}

Keywords: Ultrasound-assisted extraction, Waste ash, Titanium, Solvent mixtures.

\section{ULTRASON DESTEKLI EKSTRAKSIYYON KULLANILARAK ÇÖZÜNÜRLEŞTİRMEDEN SONRA ÇINKO KÜLÜNDEKI TITTANYUMUN FAAS İLE TAYİII}

\section{ÖZ}

Bu çalışmada, alevli atomik absorpsiyon (FAAS) kullanılarak galvaniz fabrikalarından alınan atık kül örneklerindeki Ti (titanyum) miktarının belirlenmesi amaçlanmıştır. Çeşitli galvanizleme sac veya boru proseslerinden elde edilen çinko külünün çözünürleştirilmesi için ultrases destekli ekstraksiyon kullanılarak çeşitli zaman periyotları ve farklı çözücü karışımları incelenmiştir. Galvanizli atıkta Ti metali için en iyi çözücü karışımları sırasıyla, $\mathrm{HCl}: \mathrm{HNO}_{3}: \mathrm{H}_{2} \mathrm{O}_{2}$ (1:3:2, h:h:h) $>\mathrm{HCl}>\mathrm{HNO}_{3}: \mathrm{HCl}(1: 3, \mathrm{~h}: \mathrm{h})>\mathrm{HNO}_{3}>\mathrm{HNO}_{3}: \mathrm{H}_{2} \mathrm{SO}_{4}(3: 1, \mathrm{~h}: \mathrm{h})>\mathrm{HNO}_{3}: \mathrm{H}_{2} \mathrm{SO}_{4}(1: 1, \mathrm{~h}: \mathrm{h})>$ $\mathrm{HNO}_{3}: \mathrm{H}_{2} \mathrm{SO}_{4}(3: 2$, h:h $)>\mathrm{HNO}_{3}: \mathrm{H}_{2} \mathrm{SO}_{4}(2: 1$, h:h) olarak bulunmuştur.

Anahtar Kelimeler: Ultrases destekli ekstraksiyon, Atık kül, Titanyum, Çözücü karışımları.

Sorumlu Yazar: Cemile ÖZCAN, cemilebal.ozcan@klu.edu.tr 


\section{INTRODUCTION}

The method of zinc coating applied to the surface in order to prevent corrosion in metals is called galvanization. Zinc ash is formed during the various processes of galvanizing metal sheet or pipe. In the galvanizing process, the casting, smelting and other metal industries generate large amounts of waste containing high amounts of zinc [1-4]. In the galvanizing process, while zinc and nickel are commonly used for metallic coating; Cadmium, copper, tin, chrome, gold and silver metals are also used [5]. Since the waste ash generated after the galvanizing process may contain precious metals, it should be evaluated.

Ti element, which is rare in the nature, is the most abundant element in the earth's crust, after aluminum, iron and magnesium at the rate of 6 per thousand. Ti is one of the transition metals with atomic number 22 , located in the $4 \mathrm{~B}$ group 4 th period $\mathrm{d}$ orbital in the periodic table [6]. The sparse distribution of ore and the difficulty of obtaining Ti from its ore makes it an expensive metal. The element $\mathrm{Ti}$, which is very distributed in the earth's crust, is rutile $\left(\mathrm{TiO}_{2}\right)$, ilmenite $\left(\mathrm{FeTiO}_{3}\right)$, titanomagnetite $\left(\mathrm{Fe}_{3} \mathrm{O}_{4} \cdot \mathrm{TiO}_{2}\right)$, perovskite $\left(\mathrm{CaTiO}_{3}\right)$, etc. It is one of several important ossicles and is also found in alluvial-volcanic rocks and sediments formed from them. Sediments can generally contain the heavy metals in the range of $3-12 \%$, consisting of ilmenite, rutile, leucoxene, zircon and monazite [3-4]. Ti, which is a $57 \%$ lighter metal compared to steel, has low density $\left(4.5 \mathrm{~g} / \mathrm{cm}^{3}\right)$ and good hardness, has low thermal conductivity and expansion coefficient, high melting point $\left(1660{ }^{\circ} \mathrm{C}\right)$. As it is easily processed between $-240{ }^{\circ} \mathrm{C}$ and $540{ }^{\circ} \mathrm{C}$ and has the highest corrosion resistance of all metals against atmospheric corrosion, is more resistant than steel and resistant to almost all chemical effects, titanium is a sought-after metal in aircraft, space, medical and many other fields material. In addition, it is widely used in the plastic industry and electrical applications as it increases the durability of materials against UV rays and extreme temperatures $[8,9]$.

Petry et al. determined Ti and V in Ziegler-Natta polymerization catalysts by inductively coupled plasma optical emission spectrometry (ICP-OES). They determined $0.80 \%-1.00 \%$ Ti in the catalysts used in polymerization. In addition, they determined that $\mathrm{Ti}$ in catalysts did not show homogeneous distribution with scanning electron microscope-energy dispersing X-ray (SEMEDX) device [10]. Mirzaei and Naeini conducted a study to determine the trace amount of Ti by 
flame atomic absorption spectrometer after cloud point extraction. They determined the RSD (relative standard deviation) value for Ti as 3.8\% [11].

Solvent extraction, ionexchange, ultrasound-assisted extraction and adsorption were investigated the digestion technique for removal of heavy metals from natural samples by many researchers [12-18]. In this study was used the ultrasound-assisted extraction as digestion technique.

In study, it is aimed to perform method validation and optimization by using flame atomic absorption spectroscopy (FAAS) for the analysis of total Ti in waste ash used in galvanizing process. To prepare the ash samples for analysis, different solvent mixtures were tried and the best solvent/solvent mixture was determined. During the preparation of the samples for analysis, the fast and effective SAE device (with time optimization) was used. The optimum results found were applied to the real samples.

\section{MATERIAL AND METHOD}

\section{Preparation of Standard Solutions}

In order to obtain the calibration plots used in quantitative analysis, stock and dilute solutions were prepared for $\mathrm{Ti}$ at known concentrations and metal contents were analyzed with FAAS. The standard of Ti is $1000 \mathrm{mg} / \mathrm{L}$ standard NIST (National Institute of Standard and Technology, primary standard material) stock solution. A suitable appropriate dilute (50 mg/L) solution was prepared from a $1000 \mathrm{mg} / \mathrm{L}$ stock solution. Then, standard solutions for $\mathrm{Ti}$ in the range of 1-25 $\mathrm{mg} / \mathrm{L}$ were prepared from these appropriate dilute solutions [19].

\section{Solubilization Study with Different Acid Mixtures}

Samples weighed in $0.25 \mathrm{~g}$ on analytical precision balance $5 \mathrm{~mL}$ of $\mathrm{HCl} ; \mathrm{HNO}_{3} ; \mathrm{HCl}: \mathrm{HNO}_{3}: \mathrm{H}_{2} \mathrm{O}_{2}$ (1:3:2, v:v:v); $\mathrm{HNO}_{3}: \mathrm{H}_{2} \mathrm{SO}_{4}(1: 1, \mathrm{v}: \mathrm{v}) ; \mathrm{HNO}_{3}: \mathrm{H}_{2} \mathrm{SO}_{4}(2: 1, \mathrm{v}: \mathrm{v}) ; \mathrm{HNO}_{3}: \mathrm{H}_{2} \mathrm{SO}_{4}$ (3:1, v:v); $\mathrm{HNO}_{3}: \mathrm{H}_{2} \mathrm{SO}_{4}(3: 2, \mathrm{v}: \mathrm{v})$; $\mathrm{HCl}: \mathrm{HNO}_{3}(3: 1, \mathrm{v}: \mathrm{v})$; It was dissolved in ultrasonic bath for different times (5 min; $10 \mathrm{~min} ; 20 \mathrm{~min}$; $30 \mathrm{~min}$; $60 \mathrm{~min}$ ) with solvents and centrifuged at $8000 \mathrm{rpm}$ for 15 min and decanted. In order to prevent small particles from remaining in the solution, filtering was carried out with a filter paper. The volume of the prepared solutions was completed to $10 \mathrm{~mL}$ with ultrapure water and analysed with FAAS 


\section{RESULTS}

The measurement of $\mathrm{Ti}$ was performed at a wavelength of $363.4 \mathrm{~nm}$, a slit width of $0.5 \mathrm{~nm}$, and a deuterium lamp current of $20.0 \mathrm{~mA}$ at 6.95/11.00 acetylene/ $\mathrm{N}_{2} \mathrm{O}$ gas flow.

Calibration charts of standard solutions are presented in Figure 1.

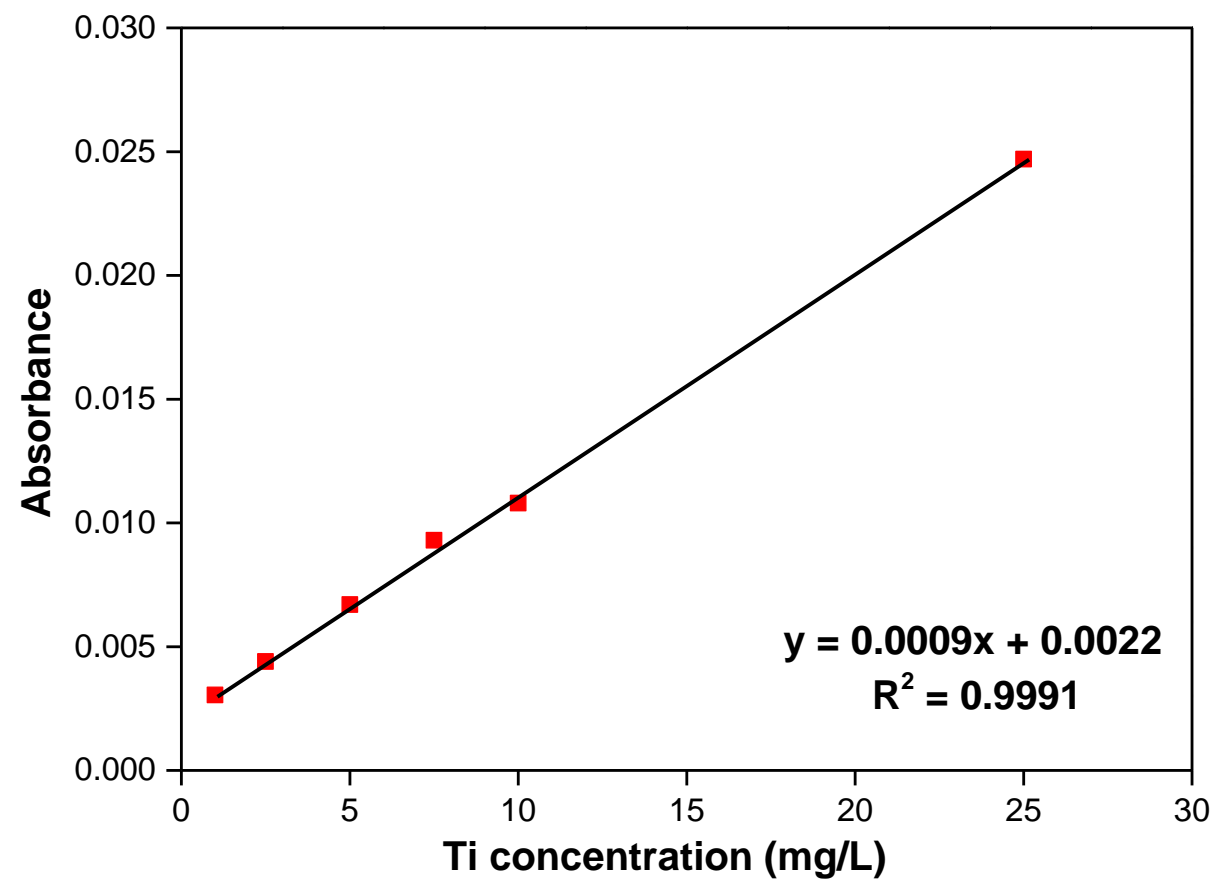

Figure 1. Ti concentration-absorbance curve determined by FAAS

The Ti concentration curve against the time obtained in the dissolution process with $\mathrm{HCl}, \mathrm{HNO}_{3}$, $\mathrm{HCl}: \mathrm{HNO}_{3}: \mathrm{H}_{2} \mathrm{O}_{2}(1: 3: 2, \mathrm{v}: \mathrm{v}: \mathrm{v})$, and $\mathrm{HNO}_{3}: \mathrm{HCl}(1: 3, \mathrm{v}: \mathrm{v})$ are given in Figure 2. 


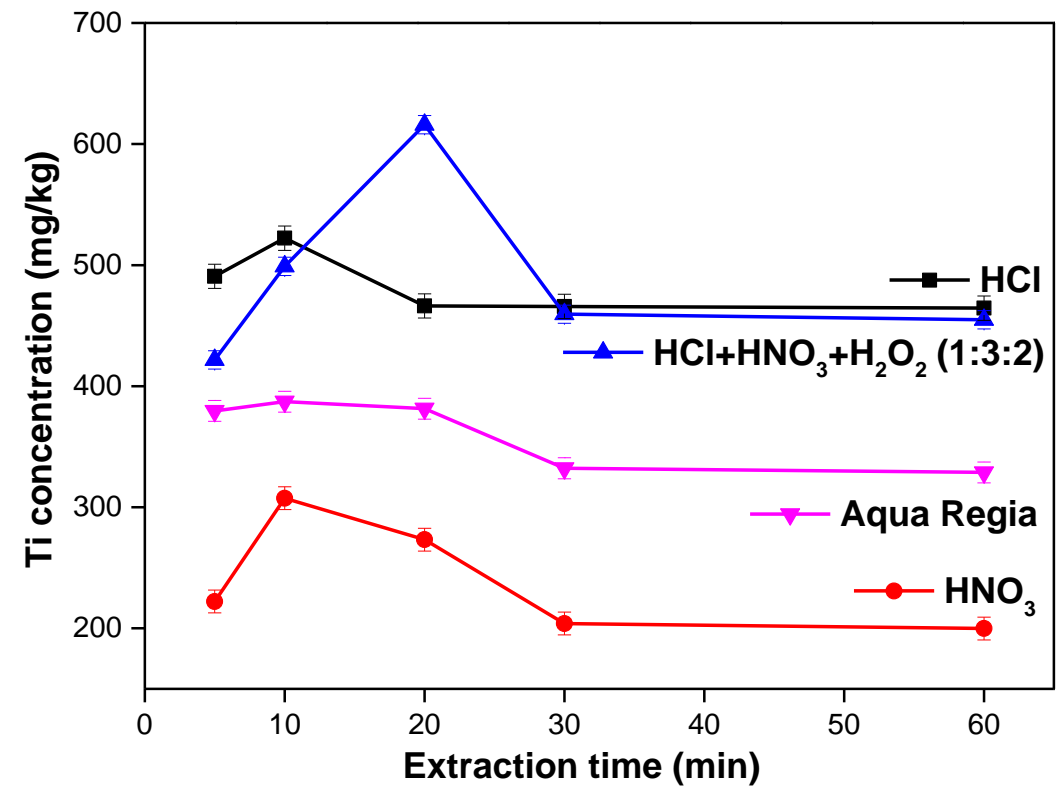

Figure 2. The best extraction time of $\mathrm{Ti}$ in the solubilization processes with $\mathrm{HCl}, \mathrm{HNO}_{3}$, $\mathrm{HCl}: \mathrm{HNO}_{3}: \mathrm{H}_{2} \mathrm{O}_{2}\left(1: 3: 2\right.$, v:v:v), and $\mathrm{HNO}_{3}: \mathrm{HCl}(1: 3, \mathrm{v}: \mathrm{v})$

The Ti concentration curve against the time obtained in the dissolving process with the mixture of $\mathrm{HNO}_{3}: \mathrm{H}_{2} \mathrm{SO}_{4}(2: 1, \mathrm{v}: \mathrm{v}), \mathrm{HNO}_{3}: \mathrm{H}_{2} \mathrm{SO}_{4}(3: 1, \mathrm{v}: \mathrm{v}), \mathrm{HNO}_{3}: \mathrm{H}_{2} \mathrm{SO}_{4}(3: 2, \mathrm{v}: \mathrm{v})$, and $\mathrm{HNO}_{3}: \mathrm{H}_{2} \mathrm{SO}_{4}(1: 1$, $\mathrm{v}: \mathrm{v})$ are given in Figure 3.

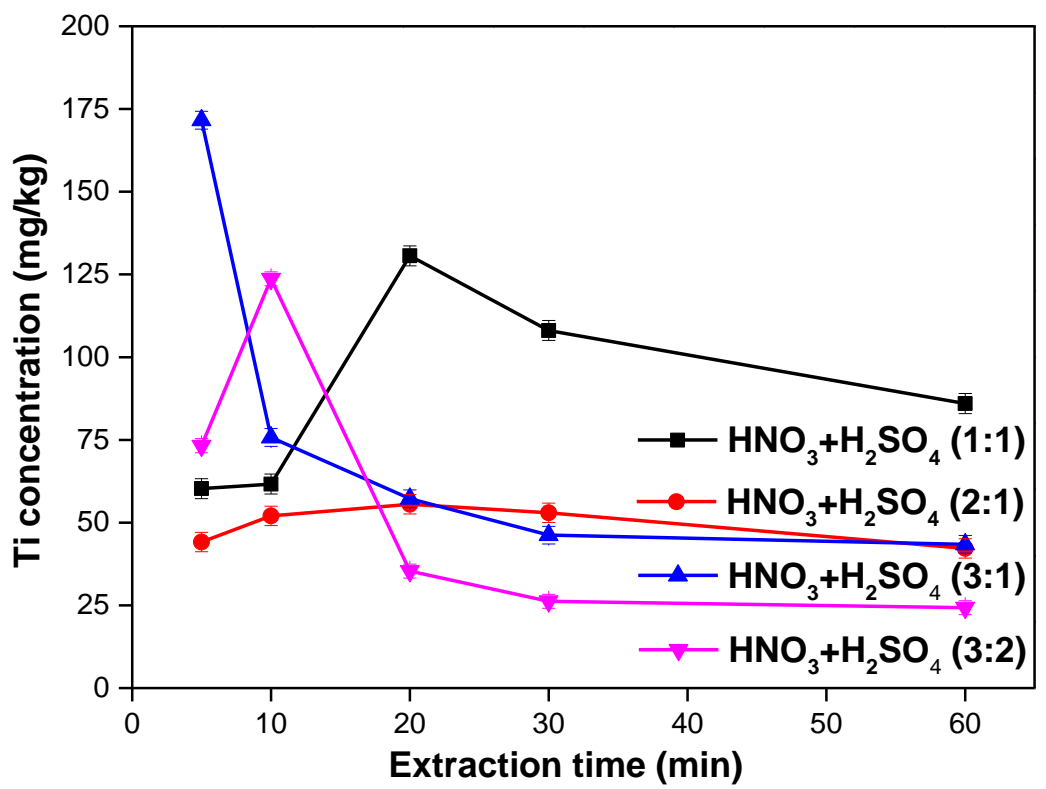

Figure 3: The best extraction time of $\mathrm{Ti}$ in the solubilization processes with $\mathrm{HNO}_{3}: \mathrm{H}_{2} \mathrm{SO}_{4}(2: 1$, $\mathrm{v}: \mathrm{v}), \mathrm{HNO}_{3}: \mathrm{H}_{2} \mathrm{SO}_{4}(3: 1, \mathrm{v}: \mathrm{v}), \mathrm{HNO}_{3}: \mathrm{H}_{2} \mathrm{SO}_{4}(3: 2, \mathrm{v}: \mathrm{v})$, and $\mathrm{HNO}_{3}: \mathrm{H}_{2} \mathrm{SO}_{4}(1: 1, \mathrm{v}: \mathrm{v})$ 


\section{CONCLUSION}

Ti; It is a material that is sought and used in many areas such as the plastic industry, electrical applications, aviation industry (in aircraft body construction, jet engines, missiles), biomedical applications, fire retardants, insulation materials, rubber, leather and textile industries, as it can be easily processed, has high corrosion resistance, and is more robust and lighter than steel.

During the preparation of the samples for analysis, the fast and effective SAE device (with time optimization) was used. Different solvent mixtures $\left(\mathrm{HCl}, \mathrm{HNO}_{3}, \mathrm{HCl}: \mathrm{HNO}_{3}: \mathrm{H}_{2} \mathrm{O}_{2}\right.$ (1:3:2, v:v:v), $\left.\mathrm{HCl}: \mathrm{HNO}_{3}(3: 1, \mathrm{v}: \mathrm{v})\right)$ and different solubilization times (5 min; $\left.10 \mathrm{~min} ; 20 \mathrm{~min} ; 30 \mathrm{~min} ; 60 \mathrm{~min}\right)$ in an ultrasonic bath were tried to prepare the ash samples for analysis. When the obtained results were examined, it was determined that the maximum dissolution process took place in 20 minutes with the mixture of $\mathrm{HCl}: \mathrm{HNO}_{3}: \mathrm{H}_{2} \mathrm{O}_{2}(1: 3: 2$, v:v:v) for Ti.

\section{REFERENCES}

[1] Dvorak, P., Jandova, J., Hydrometallurgical recovery of zinc from hot dip galvanizing ash. Hydrometallurgy, C 77, S 29-33, 2005.

[2] Ahmer, C., Maaß, P., Peißker, P., Handbook of Hot-dip Galvanization. WILLEY-VCH Verlag GmbH \& Co, KGaA, Weinheim, 2011.

[3] Delvasto, P., Casal-Ramos, J. A., González-Jordán, O., Durán-Rodríguez, N. C., DomínguezVargas, J. R., Moncada, P., Caracterización de residuos sólidos procedentes de dos procesos distintos de galvanizado en caliente por inmersión, Revista De Metalurgia, C 48(1), S 33-44, 2012.

[4] Trpcevska, J., Holkova, B., Briancin, J., Koralova, K., Piroskova J., The pyrometallurgical recovery of zinc from the coarse-grained fraction of zinc ash by centrifugal force, Int. J. Miner. Process., C 143, S 25-33, 2015.

[5]Url4<https://webdosya.csb.gov.tr/db/cygm/editordosya/Galvaniz_Kaplama_Kilavuzu.pdf〉, erişim tarihi 13.06.2020. 
[6] Ogden, H. R., Clifford, A. H., Rare Metals. Handbook, Reinhold Publishing Corporation, Chapman\&Hall Ltd., London, UK, S 559-579, 1961.

[7] Url-1<https://www.britannica.com/technology/titanium-processing/The-metal-and-its-alloys>, erişim tarihi 31.03.2020.

[8] Burke, R. A., Hazardous Materials Chemistry for Emergency Responders, CRC Press, S 51516, 2013.

[9] Bıyıkoğlu, M., Çiftçi, H., Adsorption of $\mathrm{Ag}(\mathrm{I})$ ions from wastewaters using poly(2aminothiazole): kinetic and isotherm studies, Polymer Bulletin, 77, 6161, 2020.

[10] Petry, C. F., Capeletti, L. B., Stedile, F. C., dos Santos, J. H. Z., Pozebon, D., Determination of Titanium and Vanadium in Ziegler-Natta Catalysts by Inductively Coupled Plasma Atomic Emissin Spectrometry, Analytical, Sciences, The Japan Society for Analytical Chemistry, C 22, S 855-859, 2006.

[11] Mirzaei, M., Naeini, A. K., Determination of Trace Amounts of Titanium by Flame Atomic Absorption Spectrometry after Cloud Point Extraction, Journal of Analytical Chemistry, C 68(7), S 595-599, 2013.

[12] Turan, N. B., Çağlak, A., Bakırdere, S., Engin, G. Ö., Removal of Selected Micropollutants from Synthetic Wastewater by Electrooxidation Using Oxidized Titanium and Graphite Electrodes, Clean - Soil, Air, Water, C 48, S 1900378-6 2020.

[13] Yaman, M., Okumus, N., Bakirdere, S., Akdeniz, I., Nanomaterials-based solid phase extraction and solid phase microextraction for heavy metals food toxicity; Zinc speciation in soils and relation with its concentration in fruits, Asian Journal of Chemistry, C 17(1), S 66-72, 2005.

[14] Soylak, M., Erdogan, N. D., Copper(II)-rubeanic acid coprecipitation system for separationpreconcentration of trace metal ions in environmental samples for their fame atomic absorption spectrometric determinations, Journal of Hazardous Material, C 137, S 1035-1041, 2006.

[15] Caprarescu, S., Corobea, M. C., Purcar, V., Spataru, C. I., Ianchis, R., Vasilievici, G., Vuluga, Z., San copolymer membranes with ion exchangers for $\mathrm{Cu}(\mathrm{II})$ removal from synthetic wastewater by electrodialysis, Journal of Environmental Science, C 35, S 27-37, 2015. 
[16] Tokalioglu, S., Yilmaz, V., Kartal, S., Delibas, A., Soykan, C., Synthesis of a novel chelating resin and its use for selective separation and preconcentration of some trace metals in water samples, Journal of Hazardous Material, C 169, S 593-598, 2009.

[17] Kurklu, K., Sayilgan, E., Optimization of major elements recovery from thermal power plant fy ash using Taguchi experimental design, International Journal of Environmental Science and Technology, C 17, S2645-2654, 2020.

[18] Weibel, G., Eggenberger, U., Kulik, D. A., Hummel, W., Schlumberger, S., Klink, W., Fisch, M., Mäder, U. K., Extraction of heavy metals from MSWI fy ash using hydrochloric acid and sodium chloride solution, Waste Management, C 76, S 457-471, 2018.

[19] Harris, D. C., Quantitative Chemical Analysis (8th edition) Translation Editor: Türker, A.R., Ankara, 2015. 